\title{
Potassium permanganate cleansing is an effective sanitary method for the reduction of bacterial bioload on raw Coriandrum sativum
}

\author{
Supram Hosuru Subramanya ${ }^{1 *}\left(\mathbb{D}, V^{2}\right.$ asudha Pai $^{2}$, Indira Bairy ${ }^{2}$, Niranjan Nayak', Shishir Gokhale \\ and Brijesh Sathian ${ }^{1}$
}

\begin{abstract}
Objective: Raw vegetables including flowers, leaves, stems, and roots are important carriers of food borne pathogens. We evaluated the bacteriological contamination of unwashed coriander leaves, and effectiveness of cleansing with $0.1 \%$ potassium permanganate solution as decontamination method.

Results: Significant bacterial contamination including pathogens like Salmonella species and Aeromonas species were isolated from unwashed coriander leaves. Decontamination with $0.1 \%$ potassium permanganate was found to be more effective than three steps wash with sterile water.
\end{abstract}

Keywords: Coriander leaves, Cilantro, Contamination, Potassium permanganate

\section{Introduction}

Food-borne illness outbreaks are increasing globally, leafy green are well-recognized potential sources of bacterial food-borne infections [1]. Food safety has major implications for human health. Consumption of fresh, uncooked or partially cooked vegetables plays important role in the outbreaks of food borne infections [2, 3]. Safety in consumption of leafy green vegetables is a growing concern, particularly in developing countries. These are likely to get contaminated during cultivation, transport and storage [2-4]. A recent report of the 2007 FAO/WHO meeting provided an overview of the pathogens most commonly associated with fresh fruit and vegetables (http://www.who.int/foodsafety). Fresh vegetables and herbs were implicated as vehicles for the transmission of food borne microbial infections worldwide [3]. An outbreak of Shiga toxin producing Escherichia coli infections attributed to consumption of leafy vegetables caused nearly 200 laboratory confirmed illnesses, 100 hospitalizations and few deaths in the USA in 2006 [5]. While leafy vegetables are an important part of a healthy

\footnotetext{
*Correspondence: supram.gowda@gmail.com

${ }^{1}$ Manipal College of Medical Sciences, Pokhara, Nepal

Full list of author information is available at the end of the article
}

diet, consumption of uncooked contaminated flavouring agents is a major concern.

Disinfection is important to sanitize the green leafy vegetables and fruits. Many researchers have found the efficacy of various disinfectants to reduce the bioload on ready to eat leafy green. It has been known that potassium permanganate $\left(\mathrm{KMnO}_{4}\right)$ solution is one such effective disinfectant, and many researchers used it against a wide range of microorganisms. Soriano et al. [6] and Amoah et al. [7] used potassium permanganate solution in disinfecting lettuce, and found a significant decrease in the bacterial load on these green leaves. Like lettuce, Coriander or cilantro (Coriandrum sativum) is a very commonly used edible leaf which is often garnished on cooked dishes. Besides, it is favored as a delicacy in most Asian dishes due to its unique flavor. Thus we planned to study the microbial quality of coriander leaves as these leaves in the raw state could be contaminated with one or more pathogenic microorganisms. Washing with plain water before use as is followed in many household cooking practices, cannot assure freedom from pathogens. Thus there seems to be a need for decontamination of coriander leaves before consumption. This study was, conducted to determine the microbiological quality of raw cilantro leaves and to assess the effectiveness of 
washing with $0.1 \% \mathrm{KMnO}_{4}$ solution as decontamination procedure.

\section{Main text \\ Materials and methods}

A total of 35 bundles of coriander leaves were purchased from 35 vendors stationed at 17 different vegetable markets located all around the Udupi town, India. Samples were collected in twenty visits from the vendors over a period of one and a half months between February and March 2016. Samples were collected in pre-sterilized plastic bags and transported with minimum delay to the microbiology laboratory. The roots of the specimen were trimmed aseptically and the leaves and parts of stem were chopped with sterile scissors. Chopped leaves were then aliquoted into 3 portions $\mathrm{A}, \mathrm{B}$ and $\mathrm{C}$ each weighing approximately $25-30 \mathrm{~g}$. These were processed separately.

Portion A of chopped leaves was inoculated into Selenite $\mathrm{F}$ broth (approximately $20-25 \%$ by volume) and incubated at $37^{\circ} \mathrm{C}$ for $6 \mathrm{~h}$ for enrichment of fecal pathogens like Salmonella species and Shigella species [8]. Loopful of Selenite F broth was sub-cultured on xylose lysine deoxycholate agar and examined after $14-18 \mathrm{~h}$ of incubation at $37{ }^{\circ} \mathrm{C}$. Colonies suggestive of Salmonella species or Shigella species were further studied and characterized morphologically and biochemically by VITEK automated system [8].

Portion B of samples were analysed quantitatively for total count by adding $50 \mathrm{ml}$ of sterile distilled water and manual shaking for $3 \mathrm{~min}$, with approximately 20 shakes per min. The wash content (water) was subjected to a serial tenfold dilution (1:10-1:10,000 in sterile peptone water) and $0.01 \mathrm{ml}$ volume of the neat and each dilution were inoculated onto MacConkey agar plates for determining the CFU/ml of the sample. The wash process was repeated three times and the content of water was inoculated in a similar manner. All the plates were inoculated at $37^{\circ} \mathrm{C}$ for $18-24 \mathrm{~h}$. The total bacteriological count was noted during each wash process. The different morphotypes of bacteria were further identified using standard biochemical reactions [8].

Portion $\mathrm{C}$ was dipped in $0.1 \%$ potassium permanganate solution $\left(\mathrm{KMnO}_{4}\right)$ with manual shaking of approximately 20 shakes per min, allowing a total of 10 min contact time at room temperature. The solution was decanted and fresh sterile distilled water was added to the leaves and decanted to remove the traces of $\mathrm{KMnO}_{4}$. The refilled fresh water was shaken vigorously and used to determine the colony count by adopting the same procedure as mentioned above for portion B. All experiments were conducted in duplicates and at room temperature of approximately $23^{\circ} \mathrm{C}$.

\section{Data analysis}

Data obtained were analyzed by the IBM SPSS Statistics 20 software from IBM Corporation, Armonk, New York, USA. 95\% confidence interval used to generalize all the mean counts. Viable counts were normalized by $\log$ transformation before applying $t$ test to compare with base line. $\mathrm{p}$ value $<0.05$ considered as statistically significant.

\section{Results}

Salmonella typhi was isolated from one sample of portion A (1/35). In portion B all 35 samples showed bacterial contamination with the mean viable count of $1.6 \times 10^{7} \mathrm{CFU} / \mathrm{ml}(7.2 \log 10 \mathrm{CFU} / \mathrm{ml})$. Coliform gram negative bacilli were found in all the samples. The contingency in Table 1 shows the number and percentage isolation of various bacteria. Potential pathogen Aeromonas spp. were detected in $6(17 \%)$ samples. Two or more than two types of bacteria were isolated from 95\% (33/35) of the samples. Washing steps of portion B with water revealed a mean $1.2 \log$ reduction in the viable bacterial load during first wash followed by 1.9 log reductions after second wash and 3.4 log reductions after the third wash. Compared with the findings of Portion $\mathrm{B}$, the viable count in portion $\mathrm{C}\left(\mathrm{KMnO}_{4}\right.$ wash) was reduced by 4.1 $\log$. The log reduction of bio-load with each wash steps using water and single decontamination step with potassium permanganate is depicted vide Fig. 1.

\section{Discussion}

Consumption of raw fruits and vegetables have been implicated in several food borne illnesses $[9,10]$. In

\begin{tabular}{|c|c|c|}
\hline Sample no. & Bacteria & $\begin{array}{l}\begin{array}{l}\text { Number } \\
\text { of bacterial } \\
\text { isolates (\%) } \\
\mathrm{N}=35\end{array}\end{array}$ \\
\hline 1 & Salmonella spp. & $1(2.85)$ \\
\hline 2 & Klebsiella spp. & $22(62.85)$ \\
\hline 3 & Enterobacter spp. & $21(60)$ \\
\hline 4 & Escherichia coli & $12(34.28)$ \\
\hline 5 & Citrobacter spp. & $8(22.85)$ \\
\hline 6 & Providencia spp. & $2(5.71)$ \\
\hline 7 & Morganella spp. & $1(2.87)$ \\
\hline 8 & Serratia spp. & $3(8.57)$ \\
\hline 9 & Pseudomonas spp. & $4(11.42)$ \\
\hline 10 & Aeromonas spp. & $6(17.14)$ \\
\hline 11 & Non fermenters & $8(22.85)$ \\
\hline 12 & Staphylococcus spp. & $4(11.42)$ \\
\hline
\end{tabular}


Effect of water and $\mathrm{KMnO4}$

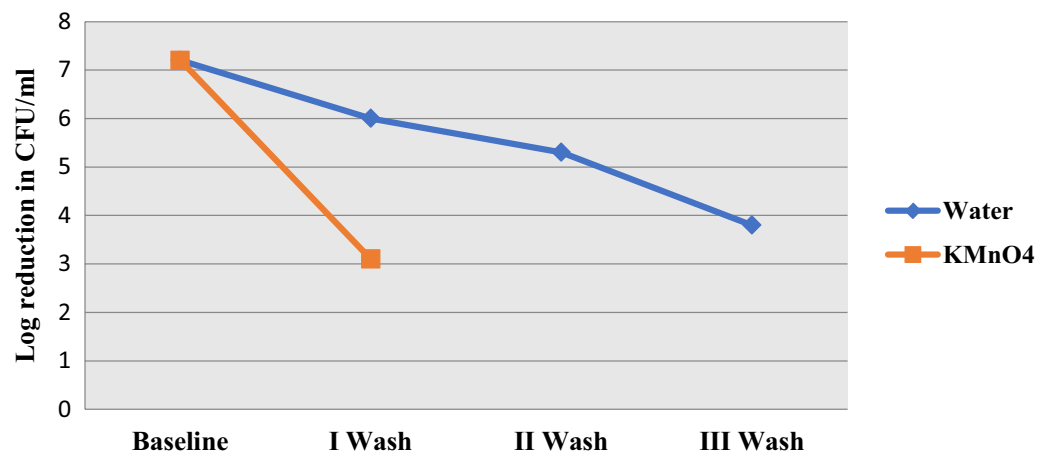

\begin{tabular}{|l|l|l|l|l|l|}
\hline Variable & $\begin{array}{l}\text { Viablecount } \\
\text { Mean } \pm \text { SD }\end{array}$ & $\begin{array}{l}\text { Log viable count } \\
\text { Mean } \pm \text { SD }\end{array}$ & $\begin{array}{l}\text { Log viable count } \\
\text { Confidence } \\
\text { Interval (CI) }\end{array}$ & P value & $\begin{array}{l}\text { Log } \\
\text { reduction }\end{array}$ \\
\hline Baseline & $1.6 \times 10^{7} \pm 0.2 \times 10^{1}$ & $7.2 \pm 0.3$ & $(7.101,7.299)$ & - & \\
\hline I wash [water] & $9.8 \times 10^{5} \pm 0.7 \times 10^{1}$ & $6.0 \pm 0.84$ & $(5.72,6.28)$ & $0.0001^{*}$ & 1.2 \\
\hline II wash [water] & $1.8 \times 10^{5} \pm 0.3 \times 10^{2}$ & $5.3 \pm 1.48$ & $(4.81,5.79)$ & $0.0001^{*}$ & 1.9 \\
\hline III wash [water] & $5.8 \times 10^{3} \pm 0.5 \times 10^{2}$ & $3.8 \pm 1.7$ & $(3.237,4.363)$ & $0.00001^{* *}$ & 3.4 \\
\hline KMnO4 & $1.3 \times 10^{3} \pm 0.1 \times 10^{2}$ & $3.1 \pm 1$ & $(2.769,3.431)$ & $0.00001^{* *}$ & 4.1 \\
\hline
\end{tabular}

Fig. 1 Viable bacterial counts of coriander leaves after sterile water and $\mathrm{KMnO}_{4}$ wash

developing countries, untreated waste water irrigation and manure as fertilizers contribute to contamination of vegetables and herbs by human and animal fecal flora [11]. If the cold chain is not maintained during transportation and storage, the bacterial multiplication may occur. Several studies demonstrated the presence of potential pathogens on fresh vegetables and leaves $[3,7,11]$. In this study, we have demonstrated the contamination of cilantro with various fecal floras which may colonize or cause infection in humans. Detection of enteric pathogens like Salmonella spp., Aeromonas spp. and Escherichia coli is a major concern. The leaves could have been contaminated in the farms during cultivation probably due to waste water irrigation. Mritunjay and Kumar [12] reported contamination of vegetable salads with pathogens like Salmonella and Enterohaemorrhagic Escherichia coli. They were of the view that the enteric bacteria would multiply in absence of effective decontamination measures during the harvesting, processing and packing. The diarrheagenic potential of $E$ coli obtained in our case could not be determined due to paucity of resources. The E coli $\mathrm{Q} 157: \mathrm{H} 7$ could survive in raw vegetables at ambient temperature retaining its infectivity. Serious illnesses ranging from bloody diarrhea to hemolytic uremic syndrome can occur due to consumption of contaminated raw vegetable [13].

In this study Pseudomonas aeruginosa, Providenia spp., Morganella spp. and Serretia spp. were detected among
$11.42,5.71,2.87$ and $8.57 \%$ of the specimen respectively. Michael et al. [14] also reported these organisms in raw vegetables. Pseudomonas aeruginosa being a common natural inhabitant of soil is likely to contaminate vegetables. Morganella and Providencia being part of normal gastrointestinal tract flora of man and animals could contaminate the soil because of open field defecation. These opportunistic pathogens can cause septicemia in immune compromised individuals. Therefore attention should be focused on the food processing, storage and transport in order to eliminate potential pathogens.

Washing the leafy vegetables with water, supposed to flush out the microorganisms is considered a satisfactory household decontamination method. But this method is influenced by various factors like availability of sufficient clean water and the original bioload on the food items. Washing with water several times is shown to reduce the bioload significantly [7], only when the washing steps are multiple, stringent and vigorous. In the present study, as well as in a similar study conducted earlier [6], sterile distilled water was used for the initial step of washing, which may not appear to be an ideal technique as this could damage the bacterial cells. However, such initial exposure to sterile distilled water for a very limited time period might not have affected the quality of the result.

Many researchers worked on the efficacy of various sanitizers and decontaminants like $\mathrm{NaCl}$ solutions, vinegar, combined salt and vinegar, laundry detergent, 
household bleach products, iodine, trisodium phosphate etc. in various concentrations and with various contact time, but none of them could completely eliminate fecal coliform populations from vegetables and fruits [9].

Of the available methods of decontamination of leafy greens, chlorination was reported to be effective, but it affects the structural integrity of leaves. The potency of common bleach is variable and unreliable. Low dose gamma irradiation was another method that efficiently reduced the microbial load while retaining the quality of leafy vegetables eaten raw [15].

Potassium permanganate solution was known to reduce the counts of pathogenic bacteria and parasites on fresh vegetables and fruits $[7,16,17]$. In this study we have observed that viable bacterial load on cilantro was reduced in a significant number by $\mathrm{KMnO}_{4}$ washing.

$\mathrm{KMnO}_{4}$ in low concentrations is often used as antiseptic mouths wash for maintenance of oral hygiene and also as a purifying agent of well water used for drinking purpose. According to recent $\mathrm{WHO}$ guidelines, $\mathrm{KMnO}_{4}$ in a concentration as low as 1:10,000 could be safe for topical application on open wounds $[18,19]$, the lethal effect being far apart corresponding to a dose as high as $10 \mathrm{gm}$ [20]. Thus washing edible items with very low concentration $(0.1 \%) \mathrm{KMnO}_{4}$ solution followed by plain water wash may not have any adverse effect on human health.

The role of education, training and awareness among the producers, handlers and consumers is important in order to improve product safety. Washing vegetables before consumption is an important approach for health risk reduction. This study showed that coriander leaves have high bacterial contamination, inclusive of pathogens like Salmonella spp., Aeromonas spp. and E coli. The decontamination effect of potassium permanganate solution on the leaves was proved to be better than the three wash steps with plain water. The effect of the $\mathrm{KMnO}_{4}$ solution on human health and taste or aroma of the leaves has not been studied in this work; this emphasized the need for further research in certain areas to facilitate the effective sanitary method.

\section{Conclusion}

The current work highlights the bacterial diversity and load on raw coriander leaves. The potassium permanganate solution at $0.1 \%$ concentration for minimum 10 min contact time proved to be an efficient and easy method to significantly reduce the bacterial load. This can be used as an alternative to or in combination with plain water washing. To the best of our knowledge, this is the first ever study demonstrating the efficacy of potassium permanganate solution as a cleanser for cilantro.

\section{Limitation}

This study involves only in vitro cultivable bacteria. Bacterial isolates were not further characterized for virulence properties or drug resistance. Effectiveness of $\mathrm{KMnO}_{4}$ washing was tested for single concentration and contact time.

\section{Abbreviations}

$\mathrm{KMnO}_{4}$ : potassium permanganate; $\mathrm{FAO}$ : Food and Agriculture Organization of the United Nations; WHO: World Health Organization; CFU: colony forming units; $\mathrm{NaCl}$ : sodium chloride.

\section{Authors' contributions \\ SHS conceived and designed the study, collected specimens, processed the specimen, analysed data and wrote the manuscript. VP contributed towards specimen collection and processing and data analysis. IB contributed towards manuscript writing and critical evaluation of manuscript. NN and SG contrib- uted towards distilling the results, discussion and manuscript preparation. BS contributed towards statistical analysis. All authors read and approved the final manuscript.}

\section{Author details}

${ }^{1}$ Manipal College of Medical Sciences, Pokhara, Nepal. ${ }^{2}$ Melaka Manipal Medical College, Manipal University, Udupi, India.

\section{Acknowledgements}

The authors gratefully acknowledge the faculty and technical staffs, department of microbiology Manipal University, India and Manipal Teaching Hospital, Nepal, for technical support. We extend our special thanks to Dr. Vandana KE, Professor of Microbiology, Kasturba Medical College, Manipal University, India, for memorable support.

\section{Competing interests}

The authors declare that they have no competing interests.

\section{Availability of data and materials}

The datasets used and/or analysed during the current study available from the corresponding author on reasonable request.

\section{Consent for publication \\ Not applicable.}

Ethics approval and consent to participate

The research proposal was approved by the Institutional Ethics Committee, Kasturba Medical College, Manipal, India.

\section{Funding}

The authors have not received any funding from any agency to support the work presented in this submission.

\section{Publisher's Note}

Springer Nature remains neutral with regard to jurisdictional claims in published maps and institutional affiliations.

Received: 29 October 2017 Accepted: 6 February 2018

Published online: 13 February 2018

References

1. FAO/WHO. Microbiological risk assessment series 14: microbiological hazards in fresh leafy vegetables and herbs. 2008b. ftp://ftp.fao.org/docre p/fao/011/i0452e/i0452e00.pdf. Accessed 15 Oct 2017.

2. Painter JA, et al. Attribution of foodborne illnesses, hospitalizations, and deaths to food commodities by using outbreak data, United States, 1998-2008. Emerg Infect Dis. 2013;19:407-15. 
3. Berger CN, Sodha SV, Shaw RK, Griffin PM, Pink D, Hand P, Frankel G. Fresh fruit and vegetables as vehicles for the transmission of human pathogens. Environ Microbiol. 2010;12(9):2385-97. https://doi.org/10.111 1/j.1462-2920.2010.02297

4. Centers for Disease Control and Prevention. Surveillance for foodborne disease outbreaks_United States, 2012: annual report. http://www.cdc gov/foodsafety/fdoss/data/annual-summaries/index.html. Accessed 14 June 2014.

5. Wendel AM, et al. Multistate outbreak of Escherichia coli O157:H7 infection associated with consumption of packaged spinach, August-September 2006: the Wisconsin investigation. Clin Infect Dis. 2009;48:1079-86.

6. Soriano JM, Rico H, Moltó JC, Mañes J. Assessment of the microbiological quality and wash treatments of lettuce served in University restaurants. Int J Food Microbiol. 2000;58(1-2):123-8.

7. Amoah P, Drechsel P, Abaidoo RC, Klutse A. Effectiveness of common and improved sanitary washing methods in selected cities of West Africa for the reduction of coliform bacteria and helminth eggs on vegetables. Trop Med Int Health. 2007;12(Suppl 2):40-50.

8. Mackey TJ, Carteney E. Practical medical microbiology of medical microbiology, vol. 2. 13th ed. London: Churchill Living Stone; 1989. p. 204

9. World Health Organisation. Surface decontamination of fruits and vegetables eaten raw: a review. 1998. http://www.who.int/foodsafety/publi cations/fs_management/surfac_decon/en/. Accessed Sept 232010.

10. Estrada-Garcia T, Lopez-Saucedo C, Zamarripa-Ayala B, et al. Prevalence of Escherichia coli and Salmonella spp. in street-vended food of open markets (tianguis) and general hygienic and trading practices in Mexico City. Epidemiol Infect. 2004;132(6):1181-4.

11. Ibrahim TA, Jude-ojei BS, Giwa EO, Adebote VT. microbiological analysis and effect of selected antibacterial agents on microbial load of fluted pumpkin, cabbage and bitter leaves. Res J Agric Biol Sci. 2009;3(4):1143-5.

12. Mritunjay SK, Kumar V. Potential hazards of microbial contamination associated with raw eaten salad vegetables and fresh produces. MiddleEast J Sci Res. 2015:23(4):741-9.

13. Eribo B, Ashenafi M. Behavior of Escherichia coli $\mathrm{O} 157: \mathrm{H7}$ in tomato and Processed tomato products. Food Res Int. 2003;36:823-30.

14. Michael JP, Chan ECS, Noel RK. Microbiology. 5th ed. New Delhi:Tata McGraw Hill; 2005. p. 793-811.

15. Kamat A, Pingulkar K, Bhushan B, Gholap A, Thomas P. Potential application of low dose gamma irradiation to improve the microbiological safety of fresh coriander leaves. Food Control. 2003;14(8):529-37.

16. Ashrafi K, Valero MA, Massoud J, et al. Plant-borne human contamination by fascioliasis. Am J Trop Med Hyg. 2006;75(2):295-302.

17. Molinos AC, Abriouel H, Ben Omar N, et al. Effect of immersion solutions containing enterocin AS-48 on Listeria monocytogenes in vegetable foods. Appl Environ Microbiol. 2005;71(12):7781-7.

18. WHO Model Formulary 2008 (PDF). World Health Organization. 2009. p. 295, 300. ISBN 9789241547659. Archived from the original on 13 December 2016. http://apps.who.int/medicinedocs/en/d/Js16879e/. Accessed 8 Jan 2017.

19. "19th WHO Model List of Essential Medicines (April 2015)". WHO. April 2015. https://www.scribd.com/document/356832183/19th-WHO-Model -List-of-Essential-Medicines-April-2015-pdf. Accessed 10 May 2017.

20. Deichmann WB, Gerarde HW. Toxicology of drugs and chemicals. New York: Academic Press; 1969

\section{Submit your next manuscript to BioMed Central and we will help you at every step:}

- We accept pre-submission inquiries

- Our selector tool helps you to find the most relevant journal

- We provide round the clock customer support

- Convenient online submission

- Thorough peer review

- Inclusion in PubMed and all major indexing services

- Maximum visibility for your research

Submit your manuscript at www.biomedcentral com/submit 